\title{
Association Between Pneumomediastinum and Renal Anomalies
}

\author{
M. M. LIBERMAN, J. M. ABRAHAM, and N. E. FRANCE \\ From the Queen Elizabeth Hospital for Children, London
}

Bilateral renal agenesis is probably always associated with hypoplastic lungs and the characteristic facial appearance described by Potter in 1946. Pulmonary hypoplasia is also frequent in infants with polycystic disease of the kidneys (Landing, 1957), in some of whom the typical Potter facies may be lacking (Bain and Scott, 1960). Newborn infants with these combinations of lesions are either stillborn or die from respiratory insufficiency soon after birth. Some show evidence of extravasation of air outside the pulmonary alveoli into the interstitial tissue, and, in severe cases, this may extend into the mediastinum and pleural sacs. If the typical facial features are lacking, the infant may present with acute respiratory distress due to pneumomediastinum, and the unsuspected underlying lung and kidney lesions may be discovered only at necropsy.

\section{Case Reports}

Case 1. A full-term male infant weighing $1505 \mathrm{~g}$. was delivered by forceps to a 35-year-old mother after a normal pregnancy. Labour was complicated by hypotonic uterine inertia in the first stage, and it was noted that the liquor amnii was scanty. At birth the infant's face looked normal. He was cyanosed, had very poor muscle tone, and bradycardia was present. Mucus was extracted through an endotracheal tube and oxygen was given by face mask. Respiration, irregular and gasping initially, was established after 15 minutes. His colour became pink, he responded to stimuli and made attempts at crying though shallow respiration continued. An $x$-ray of the thorax at 8 hours showed pneumomediastinum. Shortly afterwards he died during a cyanotic attack.

Necropsy revealed considerable air in the mediastinum, a small pneumothorax on the right side, and hypoplastic lungs. On introducing air through the trachea, leaks were shown from the right pleural surface and from the mediastinum. There was massive pulmonary haemorrhage, with an area of interstitial emphysema beneath the surface of the right base. The kidneys

Received December 20, 1968. together weighed $25 \mathrm{~g}$. (normal combined weight $14 \mathrm{~g}$.) and were polycystic.

Case 2. A second born male infant of 34 weeks' gestation, weighing 2550 g., was delivered normally by the vertex to a 26-year-old West Indian mother. The infant had a normal facies. He cried immediately after birth but had an Apgar score of 2 at 1 minute. A small amount of mucus was aspirated from the mouth. After 5 minutes he was cyanosed and had laboured respiration with marked thoracic insuction. Oxygen was given by face mask without improvement. After an unsuccessful attempt at endotracheal intubation at 20 minutes his condition continued to deteriorate. At 3 hours cyanosis became deeper, respirations were 60 per minute, and the heart sounds became faint. Heel capillary blood $p \mathrm{H}$ was 6.87 and $\mathrm{PCO}_{2} 160 \mathrm{~mm}$. $\mathrm{Hg}$. Chest $x$-ray (Fig. 1) showed a large collection of air in the anterior mediastinum, some of which was aspirated through the third left intercostal space anteriorly while oxygen was given via endotracheal tube by intermittent positive pressure of $15 \mathrm{~cm} . \mathrm{H}_{2} \mathrm{O}$. He remained deeply cyanosed. A second $x$-ray 2 hours after the first showed an increase of the mediastinal air shadow. Deep cyanosis and gasping respiration continued until death occurred at 6 hours of age.

Necropsy showed numerous air bubbles filling the anterior mediastinum and extending around the heart and behind the thymus. By introducing air under measured pressure through a rubber catheter tied into the trachea it was found that at $15 \mathrm{~cm} . \mathrm{H}_{2} \mathrm{O}$ both lungs were inflated, and at $25 \mathrm{~cm} . \mathrm{H}_{2} \mathrm{O}$ the air in the mediastinum expanded and started leaking. No air leaked from the surface of either lung. The right lung weighed $11 \mathrm{~g}$. and the left $9 \mathrm{~g}$. (normal combined weight $44 \mathrm{~g}$.). Both kidneys were hypoplastic and disorganized by cysts of varying size lined by flat epithelium (Fig. 2). There were a few apparently normal glomeruli and tubules in the intervening connective tissue. The posterior urethra was dilated above the verumontanum though no urethral valve was present; the distal urethra was extremely hypoplastic. The bladder was hypertrophied and both ureters were dilated and tortuous.

Case 3. A full-term female infant weighing $2750 \mathrm{~g}$. was born by spontaneous vertex delivery. The mother, Caucasian, aged 30 years, had had 3 normal previous 


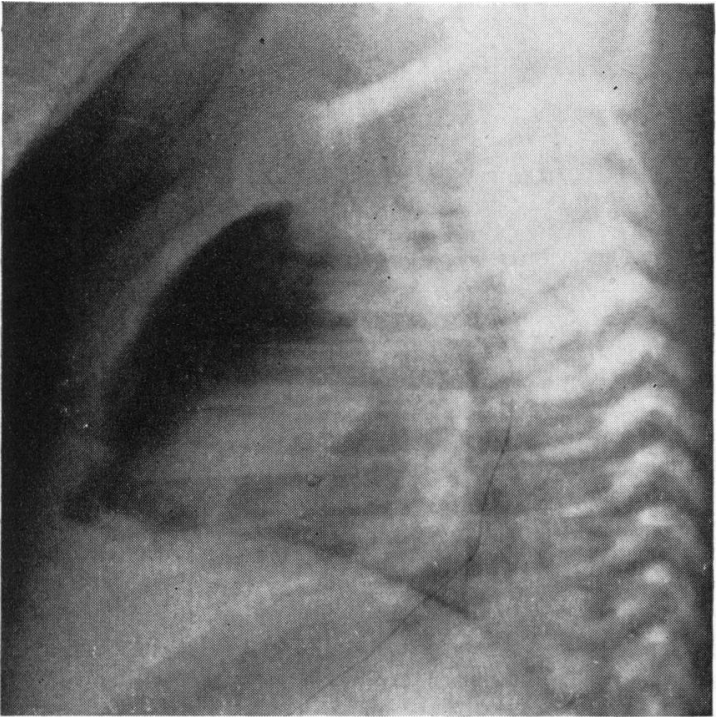

FIG. 1.-Case 2. Lateral chest $\mathrm{x}$-ray shows large collection of air in the anterior mediastinum.

pregnancies. The infant of normal facial appearance was born with the cord wound tightly around the neck. Gasping occurred at once but breathing was irregular. An Apgar rating was 0 at 1 minute and 2 at 5 minutes. Much mucus was aspirated under direct vision but no endotracheal intubation or positive pressure respiration was attempted, though oxygen was given by face mask. Respiratory distress continued with rapid shallow respirations, intercostal recession, cyanosis, and poor muscular tone. 12 hours after birth her condition had deteriorated and she was shocked, limp, and cyanosed. The respiratory rate was 120 per minute, the thorax was overdistended, the heart sounds muffled, and the peripheral pulses difficult to palpate. $X$-ray of the chest (Fig. 3) was interpreted as showing collapse of the right upper zone. Rapid deterioration ensued and she died suddenly 26 hours after birth.

Necropsy revealed a large right-sided pneumothorax with marked mediastinal emphysema. The right lung (12 g.; expected weight 29 g.) showed interstitial emphysema on the medial aspect of the lower lobe. The left lung ( $9 \mathrm{~g}$.; expected weight $20 \mathrm{~g}$.) was similarly hypoplastic but showed no interstitial emphysema. The right kidney (2 g.; expected weight 12 g.) consisted of a number of small cysts in the upper part, while the lower half showed well-differentiated cortex and medulla. The left kidney $(22 \mathrm{~g}$.) consisted of numerous large cysts with intervening pale fibrous tissue.

\section{Discussion}

The reported incidence of pneumothorax with or without pneumomediastinum varies from $0.05 \%$ to $2 \%$ of all neonates (Chernick and Avery, 1963; Morrow, Hope, and Boggs, 1967), but only sporadic cases are recorded in which death results from pneumomediastinum and renal malformation (France, Gordon, and Humphries, 1952; Howie and Weed, 1957; Chernick and Avery, 1963; Greenberg and Rabinowitz, 1963; Chasler, 1964; Passarge and Sutherland, 1965; Morrow et al., 1967). Associated pneumomediastinum and polycystic disease of the kidneys with a normal facial appearance, such as our 3 cases, has not been

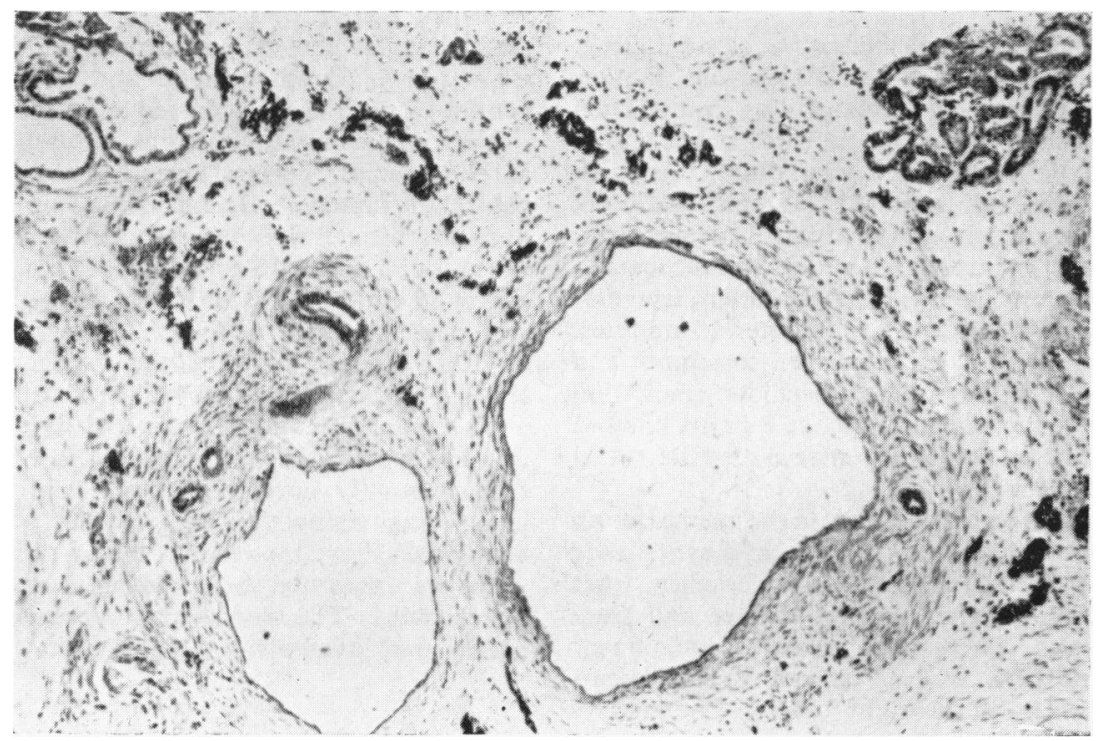

Fig. 2.-Case 2. Photomicrograph of kidney shows cysts and dysplastic tissue. (H. and E. $\times 75$.) 

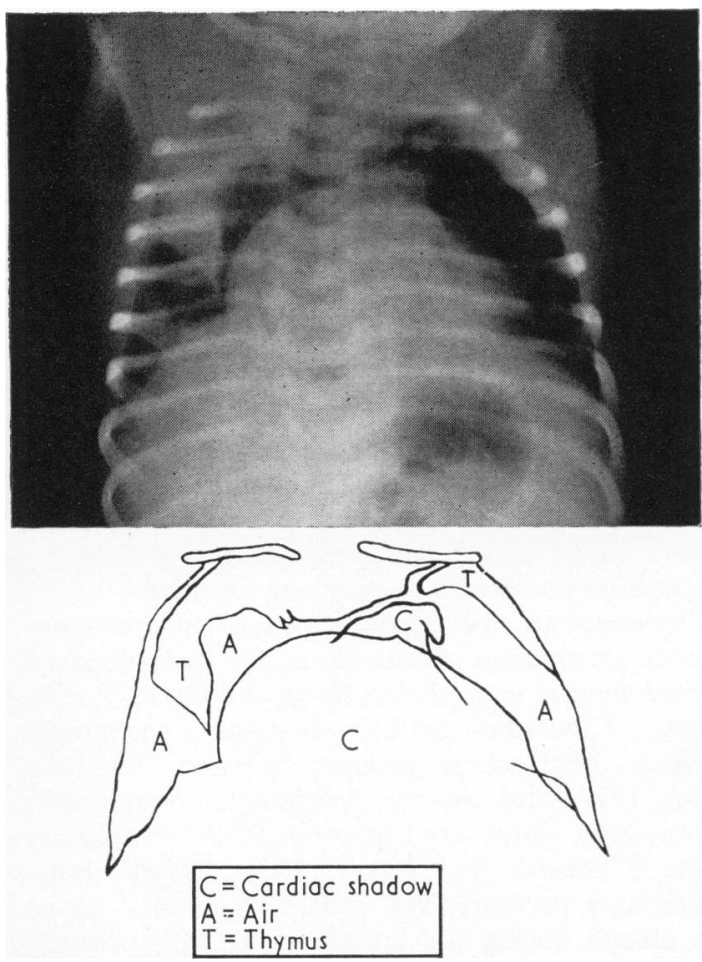

FIG. 3.-Case 3. Chest $\mathrm{x}$-ray illustrates extensive pneumomediastinum $(A)$, surrounding cardiac silhouette $(C)$, and elevation of the thymus $(T)$.

stressed previously. However, a review of the necropsy material from this hospital indicates that this combination of features is significant. Table I shows that of 20 cases of pneumomediastinum in a series of 920 necropsies on live-born infants dying within the first week of life in the period 1955 to 1966 inclusive, 9 infants (excluding the 3 reported here) had maldeveloped kidneys together with lungs which weighed less than half their normal weight. All 20 had pulmonary interstitial emphysema, and in 16 pneumothorax was also present. In 12 cases there was no history of resuscitation, while the remaining 8 had been subjected to endotracheal intubation or to the administration of oxygen under pressure via a nasal catheter or face mask. Nearly half ( 9 out of 20) of the cases of pneumomediastinum coming to necropsy and nearly a third (16 out of 51) of those with interstitial emphysema which were not resuscitated had associated hypoplastic lungs and renal anomalies. 2 infants resembled the 3 present patients in that the typical Potter facies was lacking.

Emphasis has been placed upon pulmonary hypoplasia as the most frequent single condition leading to pulmonary interstitial emphysema. However, in the 35 babies with normal kidneys and interstitial emphysema occurring spontaneously (Table I) the pulmonary lesions included pneumonia, hyaline membrane, intra-alveolar haemorrhage, and congenital lymphangiectasis, as well as uncomplicated atelectasis and aspiration of liquor amnii. Fig. 4 shows the disposition of extravasated air in the supporting tissue of the lung in one such case.

Table II illustrates the renal anomalies found in these 920 live-born babies together with 882 stillbirths examined post mortem during the same period. It shows that of 22 infants with bilateral polycystic disease of the kidneys and 6 infants with unilateral polycystic disease associated with agenesis or hypoplasia of the other kidney, no less than 22 had pulmonary hypoplasia, but only 13 of these could have been suspected from their external facial appearance. This contrasts with

TABLE I

84 Cases of Interstitial Emphysema, Pneumothorax, and Pneumomediastinum found at Necropsy in 920 Live-born Infants Dying within First Week of Life

\begin{tabular}{|c|c|c|c|c|}
\hline & \multicolumn{2}{|c|}{ Non-resuscitated } & \multicolumn{2}{|c|}{ Resuscitated } \\
\hline & $\begin{array}{c}\text { Hypoplastic Lungs } \\
\text { with } \\
\text { Abnormal Kidneys }\end{array}$ & $\begin{array}{l}\text { Normal } \\
\text { Kidneys }\end{array}$ & $\begin{array}{l}\text { Hypoplastic Lungs } \\
\text { with } \\
\text { Abnormal Kidneys }\end{array}$ & $\begin{array}{c}\text { Normal } \\
\text { Kidneys }\end{array}$ \\
\hline 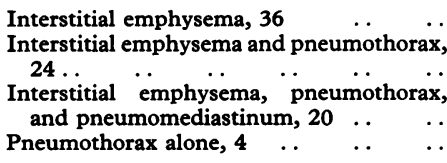 & $\begin{array}{l}8(3) \\
1 \\
7(5) \\
0\end{array}$ & $\begin{array}{l}19 \\
11 \\
5 \\
0\end{array}$ & $\begin{array}{l}0 \\
0 \\
2(2) \\
0\end{array}$ & $\begin{array}{l}9 \\
12[1] \\
6[3] \\
4\end{array}$ \\
\hline Total $\ldots \quad 84$ & 16 & 35 & 2 & 31 \\
\hline
\end{tabular}

( ) Cases showing characteristic Potter facies. [ ] Cases with tension pneumothorax. 


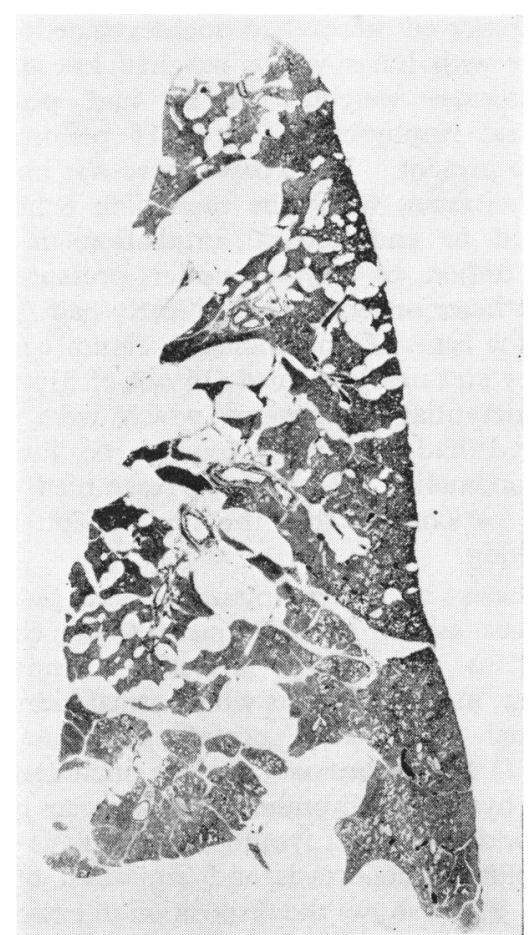

FIG. 4.-Section of whole lung illustrates distribution of interstitial emphysema. $(\times 1 \cdot 3$. the finding of both pulmonary hypoplasia and Potter facies in all 17 examples of bilateral renal agenesis, but their only occasional association with all other types of renal anomaly. Typing of the examples of bilateral polycystic disease according to Lundin and Olow (1961) showed that there was a single case of type 1 (hamartomatous), 15 of type II (polycystic with connective tissue), and 6 of type III (polycystic with hypoplasia). The incidence of pulmonary hypoplasia and Potter facies was independent of the type of renal polycystic disease present. In this series Potter facies was present in all cases of bilateral renal agenesis and in about $50 \%$ of those with bilateral severe renal anomalies. When one kidney was normal, Potter facies was never present, and pulmonary hypoplasia was found in only one example.

Spontaneous pneumomediastinum and pneumothorax occur more commonly in the early neonatal period than at any other time in childhood (Avery, 1968). Cineradiological observations of the normal lung at birth show prompt inflation (Geubelle et al., 1959), and in vitro experiments on atelectatic rabbit lung show serial inflation of the ventilatory units (Chernick and Avery, 1963). High transpulmonary pressures are transiently exerted across the alveoli during the initial phase, with pressure changes ranging up to $100 \mathrm{~cm} . \mathrm{H}_{2} \mathrm{O}$ (Karlberg et al., 1962). Any factor interfering with the rapid

TABLE II

Association of Potter Facies and Pulmonary Hypoplasia in 91 Infants with Congenital Renal Lesions (From a series of 1742 Perinatal Deaths)

\begin{tabular}{|c|c|c|c|c|c|c|c|c|c|c|c|c|}
\hline \multirow{2}{*}{$\begin{array}{c}\text { Renal } \\
\text { Anomaly } \\
\text { Associated } \\
\text { with: }\end{array}$} & \multirow{2}{*}{$\begin{array}{c}\text { Bilateral } \\
\text { Polycystic } \\
\text { Kidneys }\end{array}$} & \multicolumn{3}{|c|}{$\begin{array}{l}\text { Unilateral Polycystic } \\
\text { Kidney with } \\
\text { Contralateral: }\end{array}$} & \multirow{2}{*}{$\begin{array}{l}\text { Micro- } \\
\text { cysts }\end{array}$} & \multirow{2}{*}{$\begin{array}{c}\text { Single } \\
\text { Cyst }\end{array}$} & \multicolumn{2}{|c|}{$\begin{array}{l}\text { Agenesis of } \\
\text { Kidney }\end{array}$} & \multicolumn{2}{|c|}{$\begin{array}{l}\text { Hypoplasia and } \\
\text { Dysplasia }\end{array}$} & \multirow[b]{2}{*}{$\begin{array}{l}\text { Conjoined } \\
\text { Kidneys }\end{array}$} & \multirow[b]{2}{*}{ Total } \\
\hline & & Agenesis & $\begin{array}{c}\text { Hypo- } \\
\text { plasia } \\
\text { and } \\
\text { Dys- } \\
\text { plasia }\end{array}$ & Normal & & & Bilateral & $\begin{array}{c}\text { Unilateral } \\
\text { with } \\
\text { Other } \\
\text { Kidney } \\
\text { Normal }\end{array}$ & Bilateral & $\begin{array}{c}\text { Unilateral, } \\
\text { with } \\
\text { Other } \\
\text { Kidney } \\
\text { Normal }\end{array}$ & & \\
\hline $\begin{array}{l}\text { Pulmonary } \\
\text { hypoplasia } \\
\text { and } \\
\text { Potter } \\
\text { facies } \\
\text { Pulmonary } \\
\text { hypoplasia } \\
\text { without } \\
\text { Potter } \\
\text { facies } \\
\text { Neither } \\
\text { pulmonary } \\
\text { hypoplasia } \\
\text { nor Potter } \\
\text { facies }\end{array}$ & 11 & - & 2 & - & - & - & 17 & - & - & - & - & $\begin{array}{l}31 \\
10\end{array}$ \\
\hline Total & 22 & 1 & 5 & 5 & 8 & 1 & 17 & 13 & 4 & 1 & 14 & 91 \\
\hline
\end{tabular}

*Not including examples of anencephaly (6 cases) and diaphragmatic hernia (3 cases). 
serial aeration and expansion of alveoli may predispose to a state of prolonged, focal, high transpulmonary pressure across aerated sacs ill equipped to disperse this abnormally high force. Should this lead to rupture of an alveolus, air will preferentially track through the pulmonary interstitium along the vascular sheaths to the hilum of the lung and thence into the mediastinum (Macklin, 1939). Macklin and Macklin (1944) thought that air was more likely to rupture into a pleural sac via the mediastinal pleura rather than directly through the visceral pleura.

Prenatal interference with lung growth mainly affects bronchial and bronchiolar structure (Reid, 1967). The hypoplastic lung found in congenital diaphragmatic hernia was shown to have a greatly reduced number of bronchial generations, but the number of alveoli was within normal limits though their diameter was reduced (Areechon and Reid, 1963). No study of the structure of hypoplastic lungs in the conditions mentioned in this paper has been published. The powerful forces initiating expansion of a structurally defective lung are likely to predispose to the sequence of events described above.

Though active resuscitation in cases of respiratory difficulty at birth can produce pneumomediastinum or pneumothorax, a history of resuscitation is lacking in many cases (Prosser, 1964). Pneumomediastinum usually resolves spontaneously or, if under tension, responds to aspiration of air (Ibrahim, 1964). If no improvement is forthcoming, the underlying pulmonary lesion is probably such that positive pressure respiration will increase the mediastinal tension, as occurred in Case 2.

Though the $x$-ray appearances of pneumomediastinum are well known they are easily misinterpreted. On the postero-anterior view the large air bubble is often mistaken for a lung cyst or emphysema and the raised thymus misread as an area of collapse (Fig. 3). However, the isthmus of air separating the heart from the thymus should leave little doubt of the correct diagnosis. This should be confirmed by a lateral picture to show the air occupying the retrosternal space.

\section{Summary}

Three cases of a fatal syndrome of pneumomediastinum, hypoplastic lungs, and polycystic renal disease with normal facies are described.

The necropsy material over a 12-year period, consisting of 920 live-born infants dying in the first week of life and 882 stillbirths, is reviewed to show the association between severe extravasation of air outside the alveoli, pulmonary hypoplasia, and renal abnormalities.

It is noted that Potter facies was present in all cases of bilateral renal agenesis and in about $50 \%$ of those with bilateral renal anomalies. The presence of one normal kidney was adequate to avoid development of Potter facies.

We wish to thank Dr. Mary J. Wilmers for permission to publish the clinical details of Case 1, Dr. R. J. K. Brown for Case 2, and Dr. R. H. Dobbs for Case 3; and Dr. C. J. Hodson for his radiological opinion.

\section{REFERENCES}

Areechon, W., and Reid, L. (1963). Hypoplasia of lung with congenital diaphragmatic hernia. Brit. med. F., 1, 230.

Avery, M. E. (1968). The Lung and Its Disorders in the Newborn Infant. (Major Problems in Clinical Pediatrics, Vol. 1), 2nd ed., p. 184 . Saunders, Philadelphia.

Bain, A. D., and Scott, J. S. (1960). Renal agenesis and severe urinary tract dysplasia; a review of 50 cases, with particular reference to the associated anomalies. Brit. med. F., 1, 841.

Chasler, C. N. (1964). Pneumothorax and pneumomediastinum in the newborn. Amer. F. Roentgenol., 91, 550.

Chernick, V., and Avery, M. E. (1963). Spontaneous alveolar rupture at birth. Pediatrics, 32, 816 .

France, N. E., Gordon, I., and Humphries, F. M. (1952). Pneumothorax and pulmonary interstitial emphysema in the newborn. Arch. Dis. Childh., 27, 572.

Geubelle, F., Karlberg, P., Koch, G., Lind, J., Wallgren, G., and Wegelius, C. (1959). L'aération du poumon chez nouveau-né. Biol. Neonat. (Basel), 1, 169.

Greenberg, E. I., and Rabinowitz, J. G. (1963). Radiological notes. f. Mt Sinai Hosp., 30, 368.

Howie, V. M., and Weed, A. S. (1957). Spontaneous pneumothorax in the first 10 days of life. $\mathcal{F}$. Pediat., 50, 6.

Ibrahim, J. M. (1964). A case of tension pneumomediastinum. Lancet, 1, 642.

Karlberg, P., Cherry, R. B., Escardó, F. E., and Koch, G. (1962). Respiratory studies in newborn infants. II. Pulmonary ventilation and mechanics of breathing in the first minutes of life, including the onset of respiration. Acta paediat. (Uppsala), $\mathbf{5 1}, 121$.

Landing, B. H. (1957). Anomalies of the respiratory tract. Pediat. Clin. N. Amer., 4, 73.

Lundin, P. M., and Olow, I. (1961). Polycystic kidneys in newborns, infants and children. $A$ clinical and pathological study. Acta paediat. (Uppsala), 50, 185.

Macklin, C. C. (1939). Transport of air along sheaths of pulmonic blood vessels from alveoli to mediastinum. Arch. intern. Med., 64, 913.

Macklin, M. T., and Macklin, C. C. (1944). Malignant interstitial emphysema of the lungs and mediastinum as an important occult complication in many respiratory diseases and other conditions: an interpretation of the clinical literature in the light of laboratory experiment. Medicine (Baltimore), 23, 281.

Morrow, G., III, Hope, J. W., and Boggs, T. R., Jr. (1967). Pneumomediastinum, a silent lesion in the newborn. F. Pediat., 70, 554.

Passarge, E., and Sutherland, J. M. (1965). Potter's syndrome: chromosomal analysis of 3 cases with Potter's syndrome or related syndromes. Amer. F. Dis. Child., 109, 80.

Potter, E. L. (1946). Facial characteristics of infants with bilateral renal agenesis. Amer. F. Obstet. Gynec., 51, 885.

Prosser, R. (1964). Interstitial emphysema in the newborn. Arch. Dis. Childh., 39, 236.

Reid, L. (1967). Development of the lung. In Ciba Foundation Symposium, p. 115 . Ed. by A. V. S. de Reuck, and R. Porter. Churchill, London.

Correspondence to Dr. N. E. France, Queen Elizabeth Hospital for Children, Hackney Road, London E.2. 